\title{
Molecular identification and antibacterial properties of an ericoid associated mycorrhizal fungus
}

\author{
O. R. Adeoyo ${ }^{1,2}$, B. I. Pletschke ${ }^{1}$ and J. F. Dames ${ }^{1 *}$
}

\begin{abstract}
Background: The quest for novel sources of antibacterial compounds have necessitated the inclusion of ericoid mycorrhizal fungi (ERM) commonly found within the root of ericaceous plants. Agar-well diffusion method was used to detect antibacterial activity and was followed by the microbroth diffusion method [minimum inhibitory concentration (MIC) and minimum bactericidal concentration (MBC)].

Results: The results of the phytochemical screening indicated that only alkaloids, flavonoids, phenols, saponins, cardiac glycosides and terpenoids were present, while steroids and tannins were absent. The MIC of the extracts ranged between 2 and $16 \mathrm{mg} / \mathrm{mL}$, and the lowest MIC was obtained with Staphylococcus aureus. Also, the result of the MBC study indicated that the fungal extract was most active at concentrations of 2 and $4 \mathrm{mg} / \mathrm{mL}$ against Bacillus subtilis and S. aureus, respectively.

Conclusions: This bioassay showed, for the first time, antibacterial activity of $L$. incrustata against some bacterial species. Subsequently, ERM fungi should be given attention when searching for antimicrobial agents because they could provide a solution to solve problems associated with conventional disease treatments (i.e. pathogenic microorganisms resistance).
\end{abstract}

Keywords: Antibacterial properties, Ericoid mycorrhizal fungus, Molecular identification

\section{Background}

Mycorrhizal fungi are members of root endophytes that are capable of complex web interactions with ericaceous plants (e.g., Erica, Calluna, Rhododendron, Empetrum and Rhodothamnus species). The association that exists between ericaceous plants and mycorrhizal fungi is obligated [1]. This association plays a significant role in determining taxonomy and ensuring the growth of the host plants under harsh conditions [2]. The ericoid mycorrhizal (ERM) association is the most common root-fungus relationship in the ericaceous family [1]. Leohumicola species are among the prominent members of ericoid mycorrhizal fungi [3]. They produce two-celled aleurioconidia (single cell conidia formed by projection from the conidiophores) with a spherical to ellipsoidal, dark-brown terminal cells coupled with slightly thickened

\footnotetext{
* Correspondence: J.dames@ru.ac.za

'Department of Biochemistry and Microbiology, Rhodes University,

Grahamstown 6140, South Africa

Full list of author information is available at the end of the article
}

walls, and cylindrical or cupulate basal cells. They grow slowly on potato dextrose agar (PDA), malt extract agar (MEA) and modified Melin-Norkrans (MMN) media and are naturally found in soil, particularly, at the root of the ericaceous plants [3]. Leohumicola is a heat-resistant genus belonging to the hyphomycetes class [4]. The ribosomal small subunit (SSU) and internal transcribed spacer (ITS) sequences of Leohumicola genus revealed that the group is different from Humicola and Trichocladium (Sordariales), and Thermomyces (Eurotiales) [4]. Molecular techniques have helped a great deal in unravelling ERM fungal diversity when compared to cultural methods of identification.

Antimicrobial resistance is a significant issue hampering effective treatment of diseases. Scientists are now searching for new potent drugs from novel natural sources, and this will go a long way to support and improve human health. Antibiotic-resistance has been reported with some strains of bacteria such as Staphylococcus aureus, Escherichia coli, and Klebsiella pneumoniae, the report revealed 
that antibacterial resistance jeopardises the efficient use of drugs in prevention and treatment of different infections caused by microorganisms [5]. Staphylococcus aureus is a common causative agent of Staphylococcal infection that combines both nasal carriage and the bacterial immunoevasive strategies. The illnesses caused may be minor to life-threatening diseases [6].

Secondary metabolites from some fungi have been found to have antiviral, antidiabetic, antitumor, antioxidant, radical scavenging and antibacterial effects [7]. For example, basidiomycetes such as Fomes fomentarius, Boletus edulis, Inonotus obliquus and Piptoporus betulinus have been used to treat gastrointestinal disorders and cancers $[7,8]$. Searching for microorganisms with unique and compelling properties is highly desirable because of the burden of contending with diseases (including cancers) that affect human welfare. Phenolic compounds (polyphenols) are secondary metabolites that play a crucial role in supporting human health [9]. Phenolic compounds are made up of an aromatic ring bearing one or more hydroxyl substituent; they range from a simple molecule to complex polymerised compounds [9]. They are found in nature, particularly in foods and microorganism. They are phenolic acids, flavonoids, tannins, hydroxybenzoic (gallic and syringic acids) and hydroxycinnamic acids (caffeic, ferulic, coumaric and sinapic acids) [10]. The present study aims to carry out molecular identification of an ericoid associated mycorrhizal fungus and to determine its antibacterial properties by performing minimum inhibitory concentration (MIC) and minimum bactericidal concentration (MBC) assays. Here, for the first time, we report on an ericoid mycorrhizal isolate showing antimicrobial activity.

\section{Methods}

Fungal cultivation and production of an antibacterial agent A fungal isolate (ChemRU330) was used for the investigation. This fungus was obtained from Rhodes University, Grahamstown. Two $5 \mathrm{~mm}$ mycelial discs of the actively growing fungus was cultivated in a liquid modified MelinNorkrans (MMN) medium and was incubated at $28^{\circ} \mathrm{C}$ for three weeks, with continuous shaking at $150 \mathrm{rpm}$ on a rotary shaker. After the incubation, the fermentation broth of the fungus was homogenised and filtered through Whatman no. 1 filter paper to obtain a cell-free crude filtrate.

\section{DNA extraction}

Genomic DNA was extracted from pure fungal mycelia using the ZR Fungal/Bacterial DNA Mini-Prep kit (Catalogue \# D6005) according to manufacturer's instructions. DNA concentration was determined by NanoDrop 2000 spectrophotometer (Thermo Scientific, Wilmington, Delaware, USA) and preparations were diluted to make
$1-5 \mathrm{ng} / \mathrm{mL}$ of DNA template. The integrity of the isolated DNA was evaluated by electrophoresis in a $1 \%(\mathrm{w} / \mathrm{v})$ agarose gel at $100 \mathrm{~V}$ for $75 \mathrm{~min}$ in $1 \mathrm{X}$ Tris-borate-EDTA (TBE) buffer, stained with $2 \mu \mathrm{L}$ (concentration $0.5 \mathrm{ng} / \mathrm{mL}$ ) ethidium bromide and visualised under a Bio-Rad ChemiDoc X-Ray Spectrometer (XRS) system.

\section{Amplification of the ITS and Cox 1 gene regions}

The method described by Nguyen and Seifert (2008) was used, where the ITS region was amplified using the following primers ITS1, ITS4 and ITS5 [11] and KAPA Taq ReadyMix (2X). The KAPA Taq ReadyMix (2X) is a ready-to-use cocktail containing all components for $\mathrm{PCR}$, except primers and template. The $2 \mathrm{X}$ ReadyMix contains KAPA Taq DNA Polymerase $(1 \mathrm{U}$ per $50 \mu \mathrm{L}$ reaction), KAPA Taq Buffer, dNTPs $(0.2 \mathrm{mM}$ of each $\mathrm{dNTP}$ at $1 \mathrm{X}), \mathrm{MgCl}_{2}(1.5 \mathrm{mM}$ at $1 \mathrm{X})$ and stabilisers [12] PCR master mix was made up in a total reaction volume of $50 \mu \mathrm{l}$ comprising of $25 \mu \mathrm{L}$ KAPA Taq ReadyMix PCR kit (KAPA Biosystems, Catalogue \# KK1006), $5 \mu \mathrm{L}$ template DNA, $2 \mu \mathrm{L}$ each of both primers (forward and reverse), and $16 \mu \mathrm{L}$ of water. Amplification was conducted in an automated Applied Biosystems 2720 Thermal Cycler. The cycling parameters used were as follows: initial denaturation at $95^{\circ} \mathrm{C}$ for $3 \mathrm{~min}, 40$ cycles at $95^{\circ} \mathrm{C}$ for $45 \mathrm{~s}$ (denaturing), annealing temperature at $60^{\circ} \mathrm{C}$ for $45 \mathrm{~s}$, followed by extension at $72{ }^{\circ} \mathrm{C}$ for $1.5 \mathrm{~min}$, and finally $72{ }^{\circ} \mathrm{C}$ for $8 \mathrm{~min}$ (final elongation). After that, electrophoresis was used as previously described to determine the size of the amplified bands. The Cox 1 gene region was amplified using primers designed for the Cox1 gene of the Pezizomycotina, PezizF (5'-TCAGGRTTAYTAGGWACAGCATTT-3') and PezizR (5'-ACCTCAGGRTGYCCGAA GAAT-3') [3]. The PCR amplification was carried out in a total reaction volume of $25 \mu \mathrm{L}$ comprising of $12.5 \mu \mathrm{L}$ KAPA HiFi HotStart ReadyMix PCR kit (KAPA Biosystems, Catalogue \# KK2605), $5 \mu \mathrm{L}$ template DNA, $0.75 \mu \mathrm{L}$ each of both primers (forward and reverse) and $6 \mu \mathrm{L}$ of water. An automated Applied Biosystems 2720 Thermal Cycler was used. The initial denaturation temperature was set at $95^{\circ} \mathrm{C}$ for $3 \mathrm{~min}$, denaturation temperature at $95^{\circ} \mathrm{C}$ for $1 \mathrm{~min}$ ( 40 cycles), annealing temperature $51^{\circ} \mathrm{C}$ for $1 \mathrm{~min}$, extension temperature $72^{\circ} \mathrm{C}$ for $1 \mathrm{~min} 30 \mathrm{~s}$, and final elongation temperature $72^{\circ} \mathrm{C}$ for $8 \mathrm{~min}$ [3]. After that, electrophoresis was used as previously described to determine the size of the amplified bands.

\section{Sequencing and phylogenetic analysis}

After amplification of ITS and Cox1 barcode regions, the PCR products were cleaned up using a Wizard SV gel, and PCR clean-up kit (Promega, Catalogue \# A9281) and the protocol outlined by the manufacturer of the kit was followed. The purified PCR products were sent to Inqaba Biotechnology, Pretoria, South Africa for Sanger 
sequencing. The sequencing reaction was carried out using the respective primers for IITS region and Cox 1 gene $[13,14]$. Nucleotide sequence chromatograms were analysed and edited using Chromas Lite software and compared to sequences in National Centre for Biotechnology Information (NCBI) http://www.ncbi.nlm.nih.gov [15] and UNITE https://unite.ut.ee [16] databases using Basic Local Alignment Search Tool (BLAST) program. Sequences derived from the study and their respective closest matches with homology greater than $95 \%$ were prealigned in Chromas version 2.6.4 (www.technelysium.com. $\mathrm{au}$ ) before alignment using BioEdit sequence alignment editor version 6 [17]. To test for phylogenetic relationships, the ChemRU330 sequence and those of species in the genera Leohumicola (available in GenBank) were aligned using the ClustalX Version 1.81 [18]. Phylogenetic analysis of Cox1 barcode region was performed using molecular evolutionary genetics analysis version 7 (MEGA 7) [19]. The evolutionary history was inferred using Neighbor-Joining (NJ) statistical method [20]. The percentage of replicate trees in which the associated taxa clustered together in the bootstrap test (1000 replicates) are shown next to the branches [21]. Bootstrap support values above 50\% from 1000 replicates search. The evolutionary distances were computed using Maximum Composite Likelihood method [22] and are in the units of the base number substitutions per site. The analysis involved 25 nucleotide sequences and codon positions included were $1 s t+2 n d+3 r d+$ noncoding. All positions containing gaps and missing data were eliminated. There were a total of $628 \mathrm{bp}$ in the final dataset. Myxotrichum deflexum was chosen as an outgroup to analysis because of its status as near neighbour to Leohumicola clade in the $18 \mathrm{~S}$ analyses [4].

\section{Test bacteria}

The crude extract of each fungal isolate was screened for antibacterial activity using some bacterial strains as indicator organisms. The indicator bacteria included both Gram-positive (Bacillus subtilis and Staphylococcus aureus) and Gram-negative (Escherichia coli, Serratia marcescens, Proteus vulgaris, Shigella sonnei and Klebsiella pneumoniae) bacteria, and were obtained from the undergraduate laboratory of the Department of Biochemistry and Microbiology, Rhodes University, Grahamstown. The bacterial isolates were already identified cultures used for undergraduate practical demonstration. All bacterial cultures were adjusted to 0.5 McFarland standards, which is visually comparable to a microbial suspension of approximately $1.5 \times 10^{8} \mathrm{CFU} / \mathrm{mL}$.

\section{Preliminary screening (using crude fungal filtrate)}

The initial screening of antibacterial activity was conducted using a well-dilution method. The nutrient agar (NA) and Luria-Bertani (LB) media were poured into separate Petri plates and inoculated with $50 \mu \mathrm{L}$ of the bacterial suspension $\left(1.5 \times 10^{8} \mathrm{CFU} / \mathrm{mL}\right)$ and spread uniformly by using a sterile glass spreader. Wells $(5 \mathrm{~mm})$ were made on the agar media with a sterile cork borer, $50 \mu \mathrm{L}$ crude filtrate of each of the fungal isolate was placed into each separate well, and the controls [positive (chloramphenicol) and negative (sterile distilled water)]. Parafilm was used to seal the plates before incubation at $37^{\circ} \mathrm{C}$ for $24 \mathrm{~h}$. Plates showing antibacterial activity were confirmed by visualisation, followed by measurement of inhibition zones. The average of three repeated trials was taken to evaluate the antibacterial activity [23].

\section{Qualitative phytochemical screening}

Phytochemical screening was conducted on the ethyl acetate extract to check for the presence of the following secondary metabolites - alkaloids, flavonoids, phenols, saponins, steroids, cardiac glycosides, tannins, and terpenoids. Alkaloids: an $80 \mathrm{mg}$ of solid fungal extract was dissolved in $4 \mathrm{~mL} 2 \mathrm{~N} \mathrm{HCl}$. The sample was divided into two portions, one portion was treated with equal amount of Wagner's reagent, and the second portion was treated with equal amount of Mayers reagent. Reactions showing the appearance of a brown precipitate indicated the presences of alkaloids. Flavonoids (zinc hydrochloride reduction test): to a test-tube containing $1 \mathrm{~mL}$ of fungal crude extract, $5-10$ drops of dilute $\mathrm{HCl}, 0.5 \mathrm{~g}$ of zinc turnings were added, and the solution was boiled for $2 \mathrm{~min}$. A reddish pink or dirty brown colouration of the solution indicated the presences of flavonoids in the extract. Phenols: a $40 \mathrm{mg}$ crude extract was dissolved in $2 \mathrm{~mL}$ of distilled water. Then, a few drops of neutral $5 \% \mathrm{FeCl}_{3}$ solution was added. A dark green colour indicated the presence of phenolic compounds. Saponins: The crude extract $(1 \mathrm{~mL})$ was combined with $5 \mathrm{~mL}$ water and shaken for $2 \mathrm{~min}$. The saponins are known to possess frothing activity, the volume of foam was recorded every $10 \mathrm{~min}$. Froth more than $1.5 \mathrm{~cm}$ indicated a positive result. Steroids: steroid content was detected by using the Liebermann-Burchard reaction method. A $1 \mathrm{~mL}$ fraction of the crude extract was placed in a tube containing acetic anhydride, and a few drops of sulphuric acid $\left(\mathrm{H}_{2} \mathrm{SO}_{4}\right)$ was added. A bluish-green ring indicated the presence of steroids. Cardiac glycosides: a $1 \mathrm{~mL} \mathrm{FeCl}_{3}$ reagent (a mixture of 1 volume of $5 \% \mathrm{FeCl}_{3}$ solution and 99 volumes of glacial acetic acid) was added to $1 \mathrm{~mL}$ of the crude extract and was later treated with a few drops of $\mathrm{H}_{2} \mathrm{SO}_{4}$, carefully placed in a dropwise manner along the sides of the test tube. The appearance of greenish blue colour within a few min indicated a positive result. Tannins: the already prepared alcoholic $\mathrm{FeCl}_{3}$ reagent was mixed with the crude extract. The mixture produced a bluish-black colour, which disappears on the addition of a few drops of $\mathrm{H}_{2} \mathrm{SO}_{4}$ to yield a yellowish brown precipitate indicates a positive result. 
Terpenoids: a $1 \mathrm{~mL}$ crude extract was added to $1 \mathrm{~mL}$ of chloroform, followed by addition of 1 or 2 drops of concentrated $\mathrm{H}_{2} \mathrm{SO}_{4}$ to form a layer. A reddish-brown precipitate at the interface indicated that terpenoids were present $[24,25]$.

\section{Extraction and concentration of crude antibacterial compound}

The bioactive compound of the fungal filtrate showing inhibition after preliminary screening was then extracted by solvent extraction procedure using ethyl acetate as the organic solvent. To the filtrate, an equal volume of extracting solution (ethyl acetate) was added (ratio 1:1), this was mixed thoroughly for $10 \mathrm{~min}$ and kept for $5 \mathrm{~min}$ to obtained two clear immiscible layers. The upper tier (bioactive compound) was separated using a separating funnel. The extracting solvent was then evaporated, and the resultant compound was dried in a rotary vacuum evaporator (Buchi Rotavapor ${ }^{\circledR}$ R-200 Rotavapor System) to yield the crude metabolite [26]. The crude extract was then dissolved in distilled water and kept at $4{ }^{\circ} \mathrm{C}$. A known weighed crude extract was dissolved in distilled water before use to obtain a particular concentration.

\section{Determination of MIC and MBC (cell viability assay using MTT) by microbroth dilution method}

The concentrated crude extract was adjusted to a final concentration of $16 \mathrm{mg} / \mathrm{mL}$ using a sterile distilled water as the diluent. The test was carried out in duplicate. The MIC was determined using the micro broth dilution method in a 96-well microtiter plate. The test organisms were grown for $24 \mathrm{~h}$ at $37^{\circ} \mathrm{C} .100 \mu \mathrm{L}$ of bacterial liquid culture [(optical density adjusted to match $0.5 \mathrm{McF}$ arland standard $\left.\left(1.5 \times 10^{8} \mathrm{CFU} / \mathrm{mL}\right)\right]$, then distributed into a 96 well microtiter plate. The crude extract preparations were diluted to contain different concentrations ranging from $16,8,4,2,1,0.5,0.25,0.125,0.0625$ and $0.03125 \mathrm{mg} / \mathrm{mL}$ dilutions, and were added to the wells containing the bacterial cells. A $5 \mu \mathrm{g} / \mathrm{mL}$ chloramphenicol was used as positive control, and sterile distilled water was used as negative control for the test microorganisms, and the microtiter plates were incubated at $37^{\circ} \mathrm{C}$ for $24 \mathrm{~h}$ [27]. A $40 \mu \mathrm{l}(0.2 \mathrm{mg} / \mathrm{mL})$ thiazolyl blue tetrazolium bromide [methylthiazolyldiphenyl-tetrazolium bromide (MTT)] was added and at $37^{\circ} \mathrm{C}$ for $30 \mathrm{~min}$ to detect the MIC.
The presence of viable bacterial cells reduced the yellow dye to a pink colour. MIC is the lowest concentration that prevented change and inhibited bacterial growth. MBC was determined by removing a portion of liquid $(50 \mu \mathrm{L})$ from each well without colour change and placing it on NA, and LB agar then incubated at $37^{\circ} \mathrm{C}$ for $24 \mathrm{~h}$. The lowest concentration that yielded no growth after this culturing was regarded as the MBC. All experiments were performed in duplicate [28].

\section{Results \\ Molecular identification and phylogenetic analysis}

This ChemRU330 isolate was previously studied using ITS barcode region (ITS1F and ITS4) (Bizabani, 2015) and was identified as Leohumicola sp. Here, Cox1 gene and ITS barcode regions were used to identify it to species level. The BLAST analysis was sufficient to resolve the organism to a particular name of the ERM fungus. The fungus was determined to have percentage similarities of 99 (GenBank). The sequence of Cox1 gene matched reference Leohumicola sequences in GenBank using BLAST search (Table 1). The closest match to isolate ChemRU330 is with accession number EU678437 and a barcode region of cytochrome oxidase subunit 1 (Cox1) of 628 bp (Fig. 1). The internal transcribed spacer sequence was estimated as $590 \mathrm{bp}$ for ITS1-ITS4 (Fig. 1). The ITS sequence read obtained had $497 \mathrm{bp}$ which was adequate to allow taxonomic identification of these fungi to genus level. The maximum composite likelihood analysis of Cox1 sequences alignment revealed that the Leohumicola species form a monophyletic group in a consensus tree (Fig. 2). The bootstrap value of $78 \%$ supported the Cox 1 sequence analysis, thus inferred that the isolates (ChemRU330) belong to the Leohumicola clade (Fig. 2). The phylogenetic relationships inferred from the ITS region sequences (not shown) did not give sufficient information.

\section{Preliminary antibacterial screening}

Table 2 shows the results of initial screening for bioactive compound producing ChemRU330 isolate. In this experiment, crude extract from the isolate was used. The fungus (ChemRU330) inhibited two Gram-positive bacteria (S. aureus and B. subtilis) and had mild activity against a Gram-negative bacterium, $P$. vulgaris.

Table 1 Identification of some ericaceous plant root associated fungi

\begin{tabular}{|c|c|c|c|c|c|c|c|}
\hline Isolate & $\begin{array}{l}\text { Primer target } \\
\text { region }\end{array}$ & Genbank accession no. & Closest BLAST match & $\begin{array}{l}\text { GenBank accession } \\
\text { closest match }\end{array}$ & $\begin{array}{l}\text { Percentage } \\
\text { coverage/ } \\
\text { similarity } \\
\text { (GenBank) } \\
\end{array}$ & $\begin{array}{l}\text { Percentage } \\
\text { coverage/ } \\
\text { similarity } \\
\text { (UNITE) }\end{array}$ & $\begin{array}{l}\text { Source of } \\
\text { closest match }\end{array}$ \\
\hline ChemRU330 & Cox1 & MF374380 & Leohumicola incrustata & EU678437 & 100/99 & ND & South Africa \\
\hline ChemRU330 & ITS & MG209608 & Leohumicola sp. & KM678361 & 97/99 & 99.38 & South Africa \\
\hline
\end{tabular}




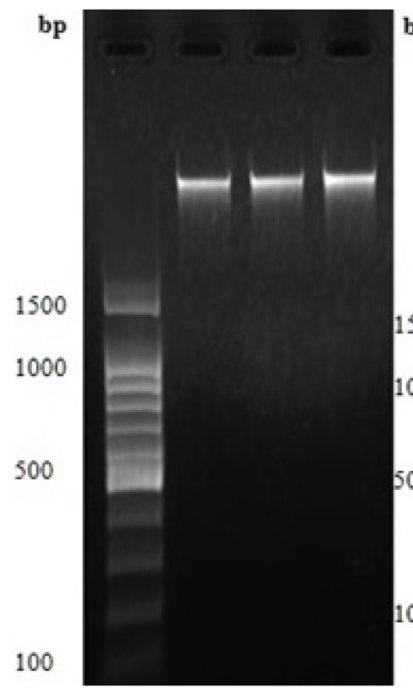

$\begin{array}{llll}1 & 2 & 3 & 4\end{array}$ bp

100

500
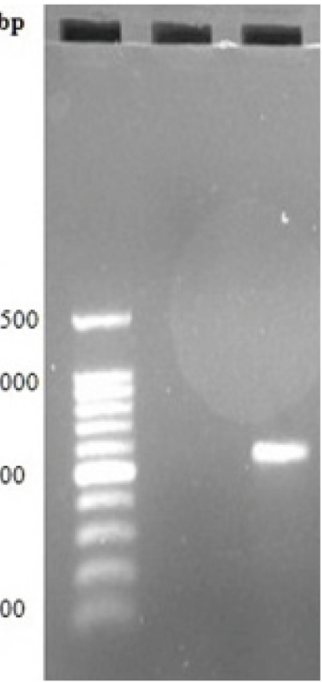

$5 \quad 6 \quad 7$

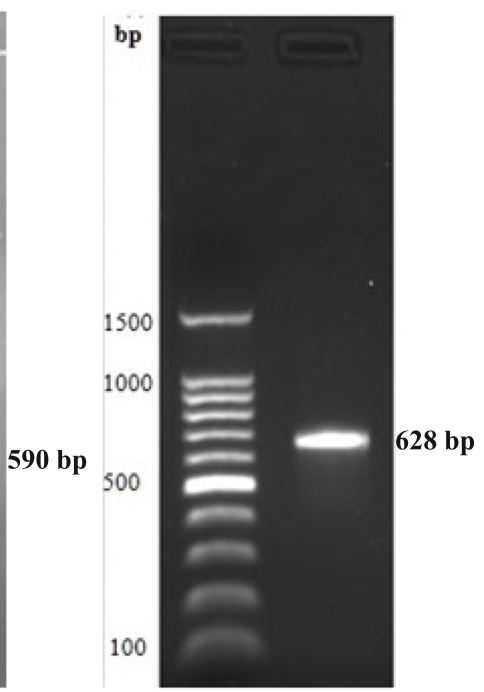

8

9

Fig. 1 PCR products from DNA extracted from ChemRU330, amplified using primers ITS1 and ITS4 and PezizF-PezizR (Cox1 gene), stained with ethidium bromide and separated by agarose gel electrophoresis. Lanes 1, 5 and 8 are $100 \mathrm{~kb}$ DNA ladder; lanes 2 to 4 are genomic DNA; lane 6 is primer control; lane 7 is amplified ITS sequence; lane 9 is amplified Cox 1 gene sequence

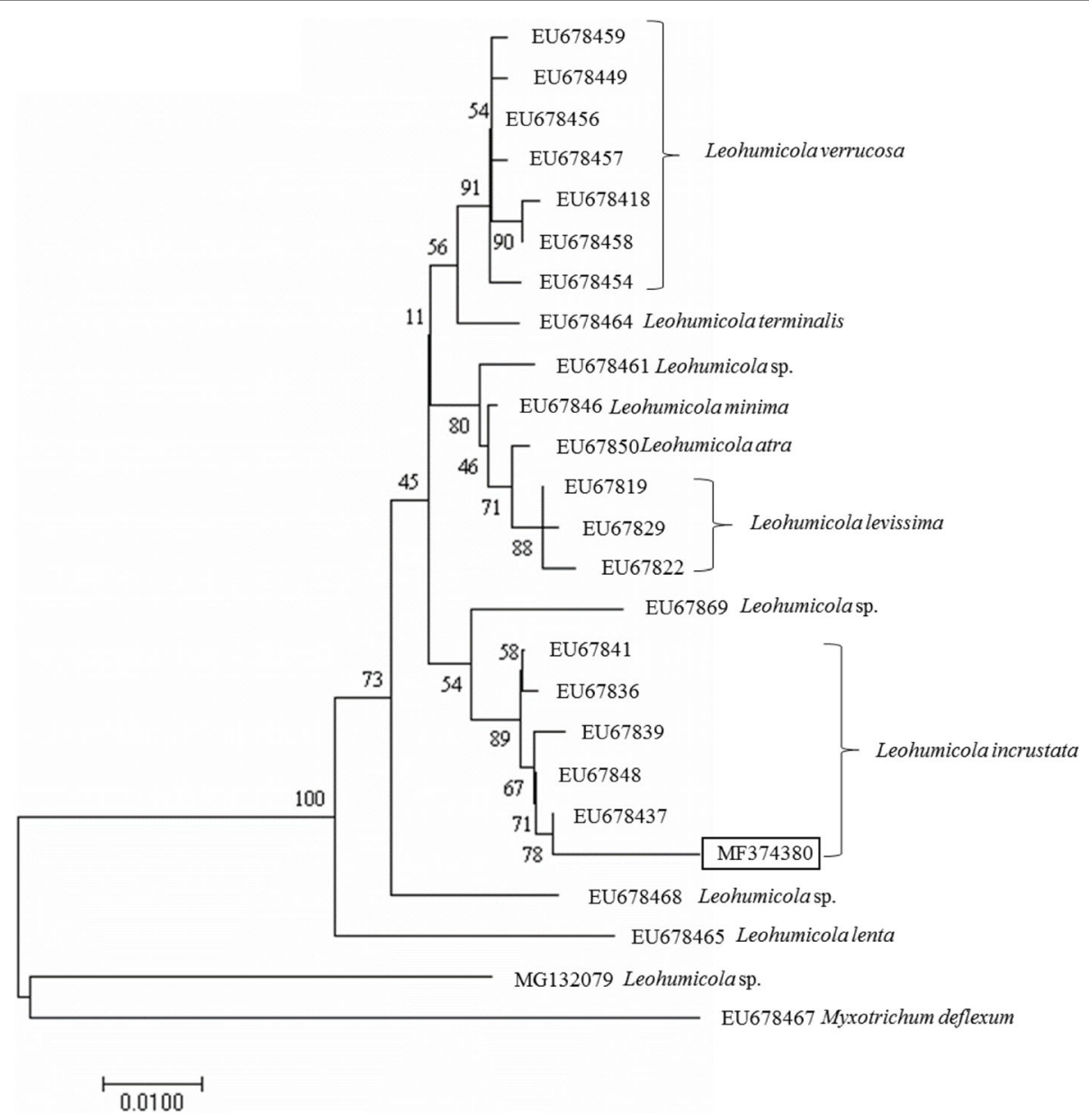

Fig. 2 Phylogenetic tree generated from cytochrome oxidase 1 (Cox1) gene sequences using the Neighbour-Joining statistical method 
Table 2 Preliminary screening for antimicrobial activity of Leohumicola (ChemRU330) extract against some bacterial species

\begin{tabular}{|c|c|c|c|c|c|c|}
\hline Sample & Bacillus subtilis & Staphylococcus aureus & Escherichia coli & Sarratia marcescens & Proteus vulgaris & Shigella sonnei Klebsiella pneumoniae \\
\hline
\end{tabular}

$\mathrm{a}_{-}=$no activity $(5 \mathrm{~mm}) ;+=$ slight activity $(6-10 \mathrm{~mm}) ;++=$ good activity $(11-15 \mathrm{~mm}) ;+++=$ very good activity $(<15 \mathrm{~mm})$

\section{Qualitative phytochemical screening}

Eight bioactive secondary metabolites that included alkaloids, flavonoids, phenols, saponins, steroids, cardiac glycosides, tannins, and terpenoids were tested for in this experiment (Table 3). The result indicated that only alkaloids, flavonoids, phenols, saponins, cardiac glycosides, and terpenoids were present while steroids and tannins were absent.

\section{Determination of MIC and MBC (cell viability assay using MTT)}

Table 4 shows that the MIC of the extracts ranged between 2 and $16 \mathrm{mg} / \mathrm{mL}$. S. aureus had the lowest MIC (1 mg/mL), followed by B. subtilis $(2 \mathrm{mg} / \mathrm{mL})$, and P. vulgaris $(16 \mathrm{mg} / \mathrm{mL})$. The results of the MBC showed that the ChemRU330 extract completely inhibited B. subtilis and $S$. aureus at the concentrations of 2 and $4 \mathrm{mg} / \mathrm{mL}$, respectively, while in the case of $P$. vulgaris, there was no growth $(\mathrm{MBC}=0)$. The $\mathrm{MBC}$ was confirmed by sampling from wells showing no visible growth as indicated by colour change and when subcultured on NA/LB media.

\section{Discussion}

A sizable number of Ericaceae root-associated fungi have been identified through culture-based techniques and molecular analysis [29]. But, there are still limited reports available on the identity of Leohumicola species using sequences generated through the ITS barcode region analysis. Subsequently, the Cox 1 barcode region was adopted to facilitate identification to species level allowing the specific name of the organism to be inferred. The ChemRU330 isolate was inferred to be L. incrustata. Similar, Nguyen and Seifert (2008) reported three new species (L. levissima, L. atra and L. incrustata) from the

Table 3 Qualitative determination of the Leohumicola incrustata extract for secondary metabolites

\begin{tabular}{lll}
\hline S/N & Phytochemical compound & Result \\
\hline 1. & Alkaloids & Positive \\
2. & Flavonoids & Positive \\
3. & Phenols & Positive \\
4. & Saponins & Positive \\
5. & Steroids & Negative \\
6. & Cardiac Glycosides & Positive \\
7. & Tannins & Negative \\
8. & Terpenoids & Positive \\
\hline
\end{tabular}

United States and South Africa using both the ribosomal internal transcribed spacer (ITS) and cytochrome oxidase 1 (Cox1) as DNA barcodes for the identification of Leohumicola species. Also, this observation was made by Hambleton co-workers (2005). A large proportion of the ERM fungi and related fungi are now being identified using both GenBank and UNITE databases [4, 30]. It should be noted that UNITE database contains ITS sequences generated from identified fungal sporocarp voucher specimens [16] and are suitable for studying mycorrhizal fungi.

For phylogenetic relationships, the taxonomic status of the ChemRU330 isolate was inferred only from the Cox1 gene sequence while ITS sequence generated in this study was inadequate for this purpose and was disregarded. Also, the results here showed that NJ statistical method is capable of producing a reasonably accurate parsimonious tree [22].

Some bacteria used were susceptible to the crude extract of Leohumicola incrustata, particularly the Grampositive bacteria. The results obtained are promising and even bacteriostatic for a Gram-negative bacterium ( $P$. vulgaris). The presence of some phenolic compounds (phenolic acids and tannins) in the extracts was responsible for the bioactivity. Reports by some authors indicated that phenolic compounds with antibacterial properties are common features of natural matrixes such as microorganisms [27, 28, 31]. Also, we observed that the slightly inhibited $S$. marcescens (Gram-negative bacterium). This agrees with the results reported earlier on E. coli, K. pneumonia and P. aeruginosa [28, 32] who noticed negative activity against these organisms. The screening for phytochemicals revealed the presence various bioactive compounds that include phenolics, alkaloids, flavonoids, cardiac glycosides and terpenoids. The production of phenolic compounds and other bioactive compounds in endophytic fungi $[24,33]$ and mushrooms $[8,28]$ have been vastly reported.

Table 4 The minimum inhibitory concentration (MIC) and minimum bactericidal concentration (MBC) values of Leohumicola incrustata extract against four bacterial isolates

\begin{tabular}{lll}
\hline Test organism & $\mathrm{MIC}(\mathrm{mg} / \mathrm{mL})$ & $\mathrm{MBC}(\mathrm{mg} / \mathrm{mL})$ \\
\hline Staphylococcus aureus & $1.0 \pm 0.36$ & $4.0 \pm 0.31$ \\
Bacillus subtilis & $2.0 \pm 0.32$ & $2.0 \pm 0.26$ \\
Sarratia marcescens & 0 & 0 \\
Proteus vulgaris & $16.0 \pm 1.73$ & 0
\end{tabular}

The values are presented as means \pm SEM (standard error of the mean), $n=3$ per treatment 
Table 5 The MIC and MBC of crude extracts of Leohumicola incrustata and some antimicrobial agents against Staphylococcus aureus

\begin{tabular}{llll}
\hline Antimicrobial agent & $\mathrm{MIC}(\mathrm{mg} / \mathrm{mL})$ & $\mathrm{MBC}(\mathrm{mg} / \mathrm{mL})$ & Reference \\
\hline L. incrustata & 1 & 4 & Current study \\
Tremetes gibbosa & 6 & 30 & {$[34]$} \\
Fusarium sp. & 0.016 & na & {$[35]$} \\
Pleurotus ostreatus & 6 & na & {$[31]$} \\
Amanita citrina & 5 & 5 & {$[8]$} \\
Xylaria sp. & 0.004 & na & {$[36]$} \\
Oxacillin & 0.002 & na & {$[37]$} \\
\hline
\end{tabular}

na $\mathrm{MBC}$ value not available

Considering the problems associated with currently available antibiotic drugs (antibiotic resistance), there is the need to discover new antimicrobial agents. In this study, the antimicrobial potential of a mycorrhizal fungus (ChemRU330) was investigated to determine the $\mathrm{MIC}$ and MBC. The results showed that the fungus contains antibacterial compounds which should be explored to complement the already available drugs for active disease treatment. The MIC reported in this study is low enough and promising for antibiotics production. Table 5 shows that the MIC value obtained against Staphylococcus aureus is similar to those reported for Tremetes gibbosa, Pleurotus ostreatus and Amanita citrina while better MIC values were reported for Xylaria sp., Fusarium sp., and Oxacillin $[8,31,34-37]$. Further purification and characterization of active compound(s) will increase the effectiveness of the antimicrobial agent. It has been suggested that antimicrobial compounds produced from fungal endophytes are highly rated because they are potent and more stable, probably due to their gene recombination with the host plant tissues [38]. Also, about 80\% of endophytic fungi have either antibacterial, fungicidal or herbicidal properties [39]. The progressive exploration of new and novel antimicrobial compounds is principally aimed at overcoming the difficulties associated with resistant pathogens [40].

\section{Conclusion}

Some root endophytic fungi such as the ERM fungi should be extensively studied and considered as additional sources of new antimicrobial agents in drug and food preservation. This bioassay showed for the first time, the antibacterial activity of $L$. incrustata against some bacterial species.

\section{Abbreviations}

Cox1: Cytochrome oxidase 1; DNA: Deoxyribonucleic acid; EMR: Ericoid mycorrhiza; ITS: Internal transcribed spacer; MBC: Minimum bacteriacidal concentration; MIC: Minimum inhibitory concentration; MMN: Modified Merlin-Norkran; MTT: Methylthiazolyldiphenyl-tetrazolium; PCR: Polymerase chain reaction

\section{Acknowledgements}

Isolates credit: Dr. Christine Bizabani, Rhodes University, Mycorrhizal Research Laboratory, Grahamstown, South Africa.

\section{Authors' contributions}

ORA, BIP and JFD made substantial contributions to conception and acquisition of data. ORA performed most of the research experiments and data analysis, BP and JD revised it critically for important intellectual content All authors were involved in data interpretation and the writing of the paper. All authors read and approved the final manuscript.

\section{Funding}

This study was funded by Rhodes University, a Sandisa Imbewu Grant, South Africa and Adekunle Ajasin University/Tertiary Education Trust Fund (TETFund), Nigeria.

\section{Availability of data and materials}

The fungal isolate used for this study was cultured from roots of ericaceous plants (Erica chamissonis) (Bizabani 2015). Leohumicola incrustata (Isolate code ChemRU330/Genbank Accession Number MF374380/The South African National Collection of Fungi Accession Number PPRI 17268), was obtained from Mycorrhizal Research Laboratory, Rhodes University, Grahamstown.

Ethics approval and consent to participate

This article does not contain any studies concerned with experiments on humans or animals.

\section{Consent for publication}

Not applicable.

\section{Competing interests}

The authors declare that they have no competing interests.

\section{Author details}

'Department of Biochemistry and Microbiology, Rhodes University, Grahamstown 6140, South Africa. ${ }^{2}$ Department of Microbiology, Adekune Ajasin University, Akungba-Akoko, Ondo State P.M.B. 001, Nigeria.

Received: 22 January 2019 Accepted: 26 July 2019

Published online: 05 August 2019

\section{References}

1. Smith SE, Read DJ. Ericoid, orchid and mycoheterotrophic mycorrhizas. Mycorrhizal Symbiosis. Third ed: Academic Press; 2008. p. 387-507. https://doi.org/10.1016/B978-0-12-370526-6.50002-7.

2. Setaro S, WeiB M, Oberwinkler F, Kottke I. Sebacinales form ectendomycorrhizas with Cavendishia nobilis, a member of the Andean clade of Ericaceae, in the mountain rain forest of southern Ecuador. New Phytol. 2006;169:355-65. https://doi.org/10.1111/j.1469-8137.2005.01583.x.

3. Nguyen HDT, Seifert KA. Description and DNA barcoding of three new species of Leohumicola from South Africa and the United States. Persoonia. 2008;21:57-69. https://doi.org/10.3767/003158508X361334.

4. Hambleton S, Nickerson NL, Seifert KA. Leohumicola, a new genus of heatresistant hyphomycetes. Stud Mycol. 2005;53:29-52. https://doi.org/10.3114/ sim.53.1.29.

5. WHO. Antimicrobial resistance. Bull World Health Organ. 2014;61:383-94. https://doi.org/10.1007/s13312-014-0374-3

6. Das MC, Biswas A, Chowdhury M, Saha J. Screening antimicrobial susceptibility of gentamicin, vancomycin, azithromycin, chloramphenico and cefotaxime against selected gram positive and gram negative bacteria. Int J Pharma Res Health Sci. 2014;2:324-31.

7. Zavastin DE, Bujor A, Tuchiluș C, Mircea CG, Gherman SP, Aprotosoaie AC. Studies on antioxidant, antihyperglycemic and antimicrobial effects of edible mushrooms Boletus edulis and Cantharellus cibarius. J Plant Dev. 2016:23:87-95.

8. Nowacka N, Nowak R, Drozd M, Olech M, Los R, Malm A. Antibacterial, antiradical potential and phenolic compounds of thirty-one polish mushrooms. PLoS One 2015;10:1-13. https://doi.org/10.1371/journal.pone.0140355.

9. Aberoumand A, Deokule SS. Comparison of phenolic compounds of some edible plants of Iran and India. Pak J Nutr. 2008;7:582-5. 
10. Balasundram N, Sundram K, Samman S. Phenolic compounds in plants and Agri-industrial by-products: antioxidant activity, occurrence, and potential uses. Food Chem. 2006;99:191-203. https://doi.org/10.1016/j.foodchem.2005. 07.042.

11. White TJ, Bruns TD, Lee SB, Taylor JW. Amplification and direct sequencing of fungal ribosomal RNA genes for phylogenetics. PCR protocol: a guide to methods and applications; 1990. p. 315-22.

12. Kapa Biosystems. Technical Data Sheet KAPA Taq ReadyMix PCR Kit. Boston; 2013. p. 1-2. https://www.kapabiosystems.com/product-applications/ products/pcr-2/kapa-taq-pcr-kits/.

13. Op De Beeck M, Lievens B, Busschaert P, Declerck S, Vangronsveld J, Colpaert JV. Comparison and validation of some ITS primer pairs useful for fungal metabarcoding studies. PLoS One. 2014:9. https://doi.org/10.1371/ journal.pone.0097629.

14. Porter TM, Brian Golding G. Are similarity- or phylogeny-based methods more appropriate for classifying internal transcribed spacer (ITS) metagenomic amplicons? New Phytol. 2011;192:775-82. https://doi.org/1 0.1111/j.1469-8137.2011.03838.x.

15. Altschul SF, Madden TL, Schäffer AA, Zhang J, Zhang Z, Miller W, et al. Gapped BLAST and PSI-BLAST: a new generation of protein database search programs. Nucleic Acids Res. 1997;25:3389-402. https://doi.org/10.1093/ nar/25.17.3389

16. Koljalg U, Larsson KH, Abarenkov K, Nilsson RH, Alexander IJ, Eberhardt U, et al. UNITE: a database providing web-based methods for the molecular identification of ectomycorrhizal fungi. New Phytol. 2005;166:1063-8. https://doi.org/10.1111/j.1469-8137.2005.01376.x.

17. Hall TA. BioEdit: a user-friendly biological sequence alignment editor and analysis program for Windows 95/98/NT. Nucleic Acids Symposium Series. 1999;41:95-8 doi:citeulike-article-id:691774.

18. Thompson JD, Gibson TJ, Plewniak F, Jeanmougin J, Higgins DG. The ClustalX windows interface: flexible strategies for multiple sequence alignment aided by quality analysis tools. Nucleis Acids Res. 1997;24:4876-82.

19. Kumar S, Stecher G, Tamura K. MEGA7: molecular evolutionary genetics analysis version 7.0 for bigger datasets. Mol Biol Evol. 2016;33:1870-4. https://doi.org/10.1093/molbev/msw054.

20. Saitou N, Nei M. The neighbor-joining method: a new method for reconstructing phylogenetic trees. Mol Biol Evol. 1987;4:406-25.

21. Felsenstein J. Confidence limits on phylogenies: an approach using the bootstrap. Evolution. 1985;39:783. https://doi.org/10.2307/2408678.

22. Tamura K, Nei M, Kumar S. Prospects for inferring very large phylogenies by using the neighbor-joining method. Proc Natl Acad Sci U S A. 2004;101: 11030-5. https://doi.org/10.1073/pnas.0404206101.

23. Hema P, Murali M, Thriveni MC, Prathibha M, Jayaramu SC, Amruthesh K Phytochemical analysis and antibacterial activity of endophytic fungi isolated from Basella rubra L. - A medicinal plant. J Pure Appl Microbiol. 2015;9:2971-8.

24. Devi NN, Prabakaran JJ, Wahab F. Phytochemical analysis and enzyme analysis of endophytic fungi from Centella asiatica. Asian Pac J Trop Biomed. 2012;2. https://doi.org/10.1016/S2221-1691(12)60400-6.

25. Singh R, Singh D, Rathod V, Naaz SA, Kumar A, Siddique S. Phytochemical analysis and antibacterial studies of the crude extracts of endophytic fungi, Colletotrichum sp. and Alternaria sp. from the medicinal plant Tridax procumbens (L). Int J Nat Products Res. 2015:5:27-33.

26. Sharma D, Pramanik A, Agrawal PK. Evaluation of bioactive secondary metabolites from endophytic fungus Pestalotiopsis neglecta BAB-5510 isolated from leaves of Cupressus torulosa D.Don. 3 Biotech. 2016;6:1-14. https://doi.org/10.1007/s13205-016-0518-3.

27. Sarker SD, Nahar L, Kumarasamy Y. Microtitre plate-based antibacterial assay incorporating resazurin as an indicator of cell growth, and its application in the in vitro antibacterial screening of phytochemicals. Methods. 2007;42: 321-4. https://doi.org/10.1016/j.ymeth.2007.01.006.

28. Alves MJ, Ferreira ICFR, Martins A, Pintado M. Antimicrobial activity of wild mushroom extracts against clinical isolates resistant to different antibiotics. J Appl Microbiol. 2012;113:466-75. https://doi.org/10.1111/j.1365-2672.2012. 05347.x.

29. Bizabani C. The diversity of root fungi associated with Erica species occurring in the Albany Centre of Endemism (PhD thesis). Rhodes University; 2015. http://hdl.handle.net/10962/d1018575.

30. Toju H, Tanabe AS, Yamamoto S, Sato H. High-coverage ITS primers for the DNA-based identification of ascomycetes and basidiomycetes in environmental samples. PLoS One. 2012;7:1-12. https://doi.org/10.1371/ journal.pone.0040863.

31. Chowdhury MMH, Kubra K, Ahmed SR. Screening of antimicrobial, antioxidant properties and bioactive compounds of some edible mushrooms cultivated in Bangladesh. Ann Clin Microbiol Antimicrob. 2015; 14:1-6. https://doi.org/10.1186/s12941-015-0067-3.

32. Barros L, Cruz T, Baptista P, Estevinho LM, Ferreira ICFR. Wild and commercial mushrooms as source of nutrients and nutraceuticals. Food Chem Toxicol. 2008;46:2742-7. https://doi.org/10.1016/j.fct.2008.04.030.

33. Bhardwaj A, Sharma D, Jadon N, Agrawal PK. Antimicrobial and phytochemical screening of endophytic fungi isolated from spikes of Pinus roxburghii. Arch Clin Microbiol. 2015;6:1-9.

34. Ratnaweera PB, de Silva ED, Williams DE, Andersen RJ. Antimicrobial activities of endophytic fungi obtained from the arid zone invasive plant Opuntia dillenii and the isolation of equisetin, from endophytic Fusarium sp. BMC Complement Altern Med. 2015;15:220.

35. Appiah T, Boakye YD, Agyare C. Antimicrobial activities and time-kill kinetics of extracts of selected Ghanaian mushrooms. Evid Based Complement Altern Med. 2017:4534350:15

36. Ratnaweera PB, Williams DE, de Silva ED, Wijesundera RLC, Dalisay DS, Andersen RJ. Helvolic acid, an antibacterial nortriterpenoid from a fungal endophyte, Xylaria sp. of orchid Anoectochilus setaceus endemic to Sri Lanka. Mycology. 2014;5(1):23-8.

37. Clinical and Laboratory Standards Institute. Performance standards for antimicrobial susceptibility testing; 27 th informational supplement. Wayne: CLSI document M100-S17. CLSI; 2017.

38. Li Y, Song YC, Liu JY, Ma YM, Tan RX. Anti-helicobacter pylori substances from endophytic fungal cultures. World J Microbiol Biotechnol. 2005;21:553-8. https://doi.org/10.1007/s11274-004-3273-2.

39. Schulz B, Boyle C, Draeger S, Römmert A, Krohn K. Endophytic fungi: a source of novel biologically active secondary metabolites. Mycol Res. 2002;106:996-1004. https://doi.org/10.1017/S0953756202006342.

40. Petersen PJ, Wang TZ, Dushin RG, Bradford PA. Comparative in vitro activities of AC98-6446, a novel semisynthetic glycopeptide derivative of the natural product mannopeptimycin alpha, and other antimicrobial agents against gram-positive clinical isolates. Antimicrob Agents Chemother. 2004;48:739-46. https://doi.org/10.1128/AAC.48.3.739-746.2004.

\section{Publisher's Note}

Springer Nature remains neutral with regard to jurisdictional claims in published maps and institutional affiliations.

Ready to submit your research? Choose BMC and benefit from:

- fast, convenient online submission

- thorough peer review by experienced researchers in your field

- rapid publication on acceptance

- support for research data, including large and complex data types

- gold Open Access which fosters wider collaboration and increased citations

- maximum visibility for your research: over $100 \mathrm{M}$ website views per year

At $\mathrm{BMC}$, research is always in progress.

Learn more biomedcentral.com/submission 